\title{
Natura 2000 and the Regulation of Agricultural Ammonia Emissions
}

\author{
Helle Tegner Anker \\ University of Copenhagen, Department of Food and Resource \\ Economics (IFRO) \\ hta@ifro.ku.dk \\ Chris W. Backes \\ Utrecht University, Utrecht Centre for Water, Oceans and Sustainability \\ Law (UCWOSL) \\ c.w.backes@uu.nl \\ Lasse Baaner \\ University of Copenhagen, Department of Food and Resource \\ Economics (IFRO) \\ lb@ifro.ku.dk \\ Andrea M. Keessen \\ Utrecht University, Utrecht Centre for Water, Oceans and Sustainability \\ Law (UCWOSL) \\ A.M.Keessen@uu.nl \\ Stefan Möckel \\ Helmholtz Centre for Environmental Research (UFz) \\ stefan.moeckel@ufz.de
}

\begin{abstract}
This article provides a comparative analysis of the regulation of ammonia emissions, primarily from livestock installations, in Denmark, Germany and the Netherlands. It discusses the challenges of regulating agricultural ammonia emissions in view of the rulings of the Court of Justice of the European Union (CJEU) on Art. 6(3) of the Habitats Directive. It is argued that the need to ensure certainty concerning the absence of significant effects on Natura 2000 sites is challenged by the uncertainties regarding


both the state of individual habitat types and the potential impact of individual projects. A more integrated or programmatic approach may provide an alternative approach to individual assessments, but it is necessary to ensure that additional loads from new or enlarged livestock installations are permitted in areas with high ammonia loads only where it is certain that a programmatic approach will ensure that there are no harmful effects. This might be an almost impossible task.

\section{Keywords}

ammonia regulation - PAS - Natura 2000 - emission regulation - CJEU - diffuse pollution - livestock installations - programmatic approach

\section{1 \\ Introduction}

In Europe, nitrogen deposition hampers the achievement of a favourable conservation status within Natura 2000 sites. ${ }^{1}$ In terrestrial ecosystems, excessive levels of reactive forms of atmospheric lead to the loss of sensitive species, and hence, biodiversity, by favouring nutrient-demanding species. ${ }^{2}$ High levels of reactive atmospheric nitrogen are the result of ammonia $\left(\mathrm{NH}_{3}\right)$ and nitrogen oxide $\left(\mathrm{NO}_{\mathrm{X}}\right)$ emissions. In countries such as Denmark, Germany and the Netherlands, ammonia emissions derive mainly from agriculture, whereas nitrogen oxides derive mainly from burning fossil fuel in transport and energy production. It is estimated that in these countries, 93.9\% (DK), 95.0\% (DE) and 86.4\% (NL) of ammonia emissions are related to agriculture. ${ }^{3}$ The three countries are comparable not only with regard to ammonia emissions from agriculture, but also to some extent in relation to the geographical scope and characteristics of Natura 2000 sites and habitat types. In this article, we focus on the regulatory framework in the three countries that addresses agricultural ammonia emissions, with a particular focus on emissions from livestock installations,

1 Natura 2000 sites comprise areas designated under the EU Habitats Directive, Council Directive 92/43/EEC on the conservation of natural habitats and of wild fauna and flora, OJ $1992 \mathrm{~L}$ 206/7 and the EU Birds Directive, Directive 2009/147/EC of the European Parliament and of the Council on the conservation of wild birds, OJ $2009 \mathrm{~L} 20 / 7$.

2 E.g. see European Environment Agency, Critical load exceedance for nitrogen, 2010, https:// www.eea.europa.eu/data-and-maps/indicators/critical-load-exceedance-for-nitrogen.

3 Eurostat/EEA, https://ec.europa.eu/eurostat/statistics-explained/index.php/ Agri-environmental_indicator_-_ammonia_emissions\#General_overview. 
although emissions from spreading of manure (or other fertilisers) will also be touched on. The article discusses the difficulty of reconciling ammonia regulation with the requirements of Article 6 of the EU Habitats Directive, as interpreted by the Court of Justice of the European Union (CJEU), and in particular the 2018 ruling of the CJEU in joined cases C-293/17 and C-294/17 regarding the Dutch programmatic approach to nitrogen (Programma Aanpak Stikstof ['Programmatic Approach to Nitrogen'], henceforth, PAS). ${ }^{4}$ The CJEU ruling has subsequently led to rejection of decisions based on the PAs by the Dutch Council of State. ${ }^{5}$

As in several previous rulings, some of the CJEU's main requirements concern the quest for (scientific) certainty or 'no reasonable scientific doubt' regarding the absence of adverse effects when determining whether a new project or plan can be approved or not. However, the actual state - and sensitivity - of habitats and species in Natura 2000 sites is characterised by a high level of uncertainty. Critical loads (CL) are often used to describe habitat sensitivity, where exceedance may indicate risk for biodiversity loss in natural and semi-natural ecosystems. Yet critical loads for the same habitat types vary from one geographical region to another. For instance, for degraded raised bogs, Danish critical loads are estimated at $5^{-10} \mathrm{~kg} \mathrm{~N} / \mathrm{ha} / \mathrm{year},{ }^{6}$ Dutch critical loads at $17 \mathrm{~kg} \mathrm{~N} / \mathrm{ha} /$ year, and German critical loads are estimated at $5^{-23} \mathrm{~kg}$ $\mathrm{N} /$ ha/year. ${ }^{7}$ This variation reflects not only scientific uncertainty about what constitutes a critical load, but also variations in methods and priorities when assessing and managing nitrogen emissions. Critical loads are exceeded for many types of habitats in many parts of all three countries. For example, in Denmark, the background deposition is estimated to be between 5 and $20 \mathrm{~kg}$ $\mathrm{N} /$ ha/year, and on average $13 \mathrm{~kg} \mathrm{~N} / \mathrm{ha} /$ year countrywide. ${ }^{8}$ In the Netherlands, the background deposition is between $400 \mathrm{~mol}$ (ca $5.7 \mathrm{~kg} \mathrm{~N} / \mathrm{ha} /$ year) on some

4 CJEU Judgment: Joined Cases C-293/17 and C-294/17 Coöperatie Mobilisation for the Environment UA, Vereniging Leefmilieu v College van gedeputeerde staten van Limburg, College van gedeputeerde staten van Gelderland [2018], ECLI:EU:C:2018:882.

5 Council of State, Administrative Jurisdiction Division, 29 May 2019, ECLI:NL:RVS:2019:1603 and ECLI:NL:RVs:2019:1604, Administratiefrechtelijke Beslissingen (AB) 2019, 308 and 309, with casenote Backes.

6 J. L. Bak Opdatering af empirisk baserede tålegrænser, Notat fra DCE, September 6, 2018, p. 8.

7 B.H. Jacobsen, H.T. Anker \& J.L Bak, Ammoniakregulering af husdyrbedrifter i forhold til ammoniakfølsom natur (Natura 2000) - sammenligning af Tyskland, Holland og Danmark. IFRO Report 273, 2018, p. 21.

8 T. Ellermann et al., Atmosfærisk deposition 2017, NOVANA, 2019, p. 19. 
islands in the Wadden Sea, and over $4000 \mathrm{~mol}$ (ca $57 \mathrm{~kg} \mathrm{~N} / \mathrm{ha} / \mathrm{year}$ ) in some of the eastern parts of the Netherlands. ${ }^{9}$

Despite a general reduction in ammonia emissions by $24 \%$ since 1990, predictions up to 2020 indicate that the risk of exceeding critical loads remains high, irrespective of the implementation of current policies and measures to reduce nitrogen emissions. ${ }^{10}$ It will be very challenging to reduce nitrogen deposition in all Natura 2000 sites to a level below the critical loads. Recent measurements in the Netherlands have shown that the predicted and calculated decrease in ammonia emissions and depositions did not occur. In fact, in some areas, the former trend of decreasing depositions reversed, and both ammonia emissions and depositions again increased. ${ }^{11}$ Agricultural ammonia emissions are a (main) source of pollution, among several other sources that may negatively affect Natura 2000 sites. Regulating agricultural ammonia emissions with regard to Natura 2000 sites requires not only knowledge about the potential emissions, but also extensive knowledge about the vulnerability of species and habitat types, and thorough knowledge about the effects of measures directed at avoiding or reducing the negative effects of nitrogen deposition.

Different regulatory measures may be applied to curb agricultural ammonia emissions, and to remedy its adverse effects on natural or semi-natural areas. A distinction may be made between general standards, such as general requirements for certain technologies, and specific and project-related assessment and permit requirements. In addition, (pro)active or restorative management measures are particularly relevant with regard to achieving favourable conservation status of habitats. From a legal perspective, the focus is often on individual assessment and permit requirements for new or amended projects, based on Article 6(3) Habitats Directive, whereas the often more vaguely formulated obligations regarding (pro-)active or restorative management measures for achieving a favourable conservation status, based on the Article 6(1) and (2) Habitats Directive, are less explored. However, from the perspective of nature protection, a predominant project assessment approach has certain limitations, as it focuses on avoiding new emissions, while leaving existing emissions largely unaffected.

9 See the maps provided by the RIVM, http://geodata.rivm.nl/gcn/.

10 Eurostat. Agri-environmental indicators - ammonia emissions, Eurostat Statistics Explained, https://ec.europa.eu/eurostat/statistics-explained/index.php/Agri-environmental _indicator_-_ammonia_emissions.

11 L. Bekker \& W. Heijligers, Tussenevaluatie Programma Aanpak Stikstof, 2018, p. $44 \mathrm{ff}$. 
An integrated management approach that includes both measures to reduce existing emissions and measures to improve the quality of the respective habitats as stipulated in Article 6(1) and 6(2), may yield better results. In some jurisdictions, including in the Netherlands, combining or integrating a project approach with proactive and restorative management measures has been labelled the 'programmatic approach.12 A programmatic approach "delinks" the individual projects assessment by providing an appropriate assessment at a more aggregate level linked to a programme. The programme is aimed at ensuring that the environmental objectives, e.g. a favourable conservation status, will be achieved by a combination of different measures that may reduce or outbalance potential adverse effects of individual projects. Given the emission reduction required to improve the quality of habitats and of species, and the possibility of other measures improving the quality of the respective habitats, a programmatic approach could be used to halt habitat degradation and improve the ecological status of the habitats concerned, whilst offering some flexibility for economic development. However, such a programmatic approach faces several challenges, and must meet the requirements of the $\mathrm{Ar}$ ticle 6 Habitats Directive, as interpreted by the CJEU. ${ }^{13}$

The CJEU's 2018 ruling on the Dutch PAS raises three important questions for the regulation of agricultural ammonia emissions. The first question relates to what is subject to consideration under Article 6(3), that is, what constitutes a project, and in particular, under which circumstances grazing and manure spreading may be considered projects. The second - and crucial - question is how to determine potential adverse effects, and in particular, whether and which thresholds may be used for either screening or appropriate assessment under Article 6(3) of the Habitats Directive. The third question relates to the feasibility of a programmatic approach, in particular, if and to what extent the effect of planned or executed management measures may be taken into consideration under Article 6(3).

From a comparative perspective, the foregoing questions will be further elaborated below, based on a short account of Article 6 of the Habitats

12 E.g. see $L$. Squintani \& H. van Rijswick, Improving legal certainty and adaptability in the programmatic approach, JEL 2016 (28), p. 443.

13 H. Schoukens, Reconciling adaptive management strategies with the EU nature directives: the unfortunate case of the Dutch integrated approach to nitrogen, in. H.T. Anker \& B.E. Olsen (eds.) Sustainable Management of Natural Resources. Legal Instruments and Approaches, 2018, pp. 155-175. H. Schoukens, Nitrogen deposition, habitat restoration and the EU Habitats Directive: moving beyond the deadlock with the Dutch programmatic nitrogen approach? Biological Conservation 2017 (2012B), p. 484. 
Directive, in view of the CJEU rulings (section 2). We will then analyse the regulation of agricultural ammonia emissions in Denmark, Germany and the Netherlands with regard to the requirements of the Habitats Directive (section 3). This section is based on a comparative study of ammonia regulation of livestock installations in Denmark, Germany and the Netherlands. ${ }^{14}$ Section 4 further discusses the legal and regulatory challenges of regulating agricultural ammonia emissions in view of the comparative analysis and the CJEU's rulings. Finally, some conclusions will be drawn in section 5 .

It is argued that a predominant focus on individual assessment and permit requirements is ineffective for contributing to a favourable conservation status of Natura 2000 sites. The need to demonstrate certainty of the absence of significant effects on the sites is challenged by the uncertainties inherent to both the state of individual habitat types and the potential impact of individual projects, particularly small-scale projects. The project approach is likely to lead to a deadlock involving huge administrative and societal costs, without achieving the necessary improvements to the state of habitats. Not only is a more integrated or programmatic approach foreseen by Articles 6(1) and 6(2), but could also be an effective option for overcoming the challenges of Article 6(3), particularly with regard to cumulative effects. Nevertheless, a programmatic approach faces several challenges and the case law of the Court of Justice raises high hurdles, which are not easy to overleap.

\section{The EU Habitats Directive as Interpreted by the CJEU}

The EU Habitats Directive imposes different obligations on the Member States concerning the protection of Natura 2000 sites. The overall objective is to achieve a favourable conservation status for the habitat types and species for the protection of which the Natura 2000 sites have been designated..$^{15}$ The Habitats Directive defines favourable conservation status of natural habitat

14 This comparative study was initiated by the Danish Environment \& Agriculture Ministry, and comprises comparative analyses from legal, economic and natural science perspectives. The project reports are available at https://ifro.ku.dk/english/research/projects/ projects_environment/ammonia_regulation-of-livestock/. See also Jacobsen et.al., Costs of regulating ammonia emissions from livestock farms near Natura 2000 areas - analyses of case farms from Germany, Netherlands and Denmark, Journal of Environmental Management, 2019 (forthcoming).

15 See Annexes I and II of the Habitats Directive regarding the relevant habitat types and species, and Annex I of the Birds Directive. 
types as, 'when: its natural range and areas it covers within that range are stable or increasing, and the specific structure and functions which are necessary for its long-term maintenance exist and are likely to continue to exist for the foreseeable future, and the conservation status of its typical species is favourable.'

The Habitats Directive appears to allow the Member States some discretion in determining the level at which favourable conservation status should be achieved, for example, individual site level, national level or even EU level. ${ }^{16}$ The existence of some variation among the Member States regarding the objectives established for the protected habitat types and species, and the abovementioned variations associated with establishing critical loads for the habitat types, are important starting points for comparing how Member States have implemented the requirements of the Habitats Directive, particularly the requirements of Article 6.

In general, the requirements of the Habitats Directive with regard to protecting Natura 2000 sites may be divided into three main obligations:

1. Establish (pro-)active or restorative management measures to restore or maintain a favourable conservation status - Article 6(1 $)^{17}$

2. Avoid deterioration of habitat types or habitats of species, e.g. by restricting existing harmful activities, cf. Article 6(2)

3. Control new (or amended) projects and plans, and ensure that they do not cause adverse effects, cf. Article 6(3)

While the obligation to take active management measures does not precisely define what actions should be taken, or when, the obligation to control (new) projects and plans is much clearer and has been subject to extensive and strict interpretation by the CJEU. The Article 6(2) obligation to avoid deterioration may be seen as an extension of the Article 6(1) obligation to take active measures, by expressing a (relatively clear) obligation to take measures to at least avoid deterioration, e.g. from existing activities. However, the more precise scope of this obligation to avoid deterioration has not been clearly defined by either Article 6(2) or by the CJEU rulings, except in cases where it

16 Schoukens, supra note 13. A. Trouwborst, L. Boitani \& J.D.C. Linnell, Interpreting 'favourable conservation status' for large carnivores in Europe: how many are needed and how many are wanted? Biodivers. Conserv. 2017 (26), p. 37.

17 Article 6(1) applies only to sites, Special Areas of Conservation (sACs), designated under the Habitats Directive, whereas the active protection of sites, Special Protection Areas (SPAs), designated under the Birds Directive, is governed by Article 3 and Article 4(1-3) of the Birds Directive. 
has been clear that no or insufficient action has been taken to address obvious deterioration. ${ }^{18}$ Nevertheless, the wording of Articles 6(1) and 6(2) makes clear that the Member States must address both the unfavourable status of habitat types and species, and those activities that may cause (continued) deterioration of the habitat types and species, for instance, by ammonia emissions. This could include measures to restrict or close down existing livestock installations. ${ }^{19}$

When it comes to the obligation to control new (or amended) projects and plans, as prescribed by Article 6(3), the CJEU has established a strict interpretation based on the precautionary principle. ${ }^{20}$ The first step is to determine whether or not an appropriate assessment is needed, sometimes called a 'screening requirement'. The screening step is not explicitly addressed in Article 6(3), but reflects the need to examine whether in a specific case an appropriate assessment must be made. If the need for such an assessment is clear from the outset, a screening step obviously is not needed. This step concerns a preliminary, summary examination of the criteria in the appropriate assessment. According to the CJEU, an appropriate assessment is not necessary for projects (and plans), if, based on objective information, the possibility of significant effects on the site's integrity can be excluded. ${ }^{21}$ In the case of remaining doubt, a full, appropriate assessment must be carried out, even for projects

18 CJEU Judgment: Case C-117/oo, Commission v Ireland [2002] ECLI:EU:C:2002:366. CJEU Judgment: Case C-404/og Commission v Spain [2011] ECLI:EU:C:2011:768. For more comprehensive analyses see $A$. Cliquet, About blanket bogs, brown bears and oak forests: case law of the European Court of Justice on Article 6(2) of the Habitats Directive, in C.H. Born \& F. Jongen (eds.) d'Urbanisme et d'Environnement: Liber Amicorum Francis Haumont, 2015, p. 531. H. Schoukens, Non-Regression Clauses in Times of Ecological Restoration Law: Article 6(2) of the EU Habitats Directive as an unusual ally to restore Natura 200o?, Utrecht Law Review 2017 (13), p. 124.

19 H. Schoukens, Atmospheric Nitrogen Deposition and the Habitats Directive: Tinkering with the Law in the Face of the Precautionary Principle? Nordic Environmental Law Journal (2/2015), p. 25 .

20 For the scope of application and the requirements of the appropriate assessment in greater detail, see, for example H. Schoukens, Proactive Habitat Restoration and the Avoidance of Adverse Effects on Protected Areas, Journal of International Wildlife Law and Policy 2017 (20), p. 125. S. Möckel, The European ecological network 'Natura 200o' and the appropriate assessment of projects and plans under Article 6(3) of the Habitats Directive, Nature Conservation 2017 (23) p. 1-29. S. Möckel, The European ecological network 'Natura 2000' and its derogation procedure to ensure compatibility with competing public interests, Nature Conservation 2017 (23), p. 87-116.

CJEU Judgement: Case C-127/o2 Waddenzee [2004] ECLI:EU:C:2004:482, para. 44. 
at a considerable distance from a Natura 2000 site. ${ }^{22}$ In a recent case, the Court held that in a screening it is inappropriate to consider measures intended to avoid or reduce the harmful effects of a plan or project. ${ }^{23}$

If an appropriate assessment of a project or plan is required, it must be based on the best scientific knowledge, ${ }^{24}$ and it 'may not have lacunae and must contain complete, precise and definitive findings and conclusions capable of removing all reasonable scientific doubt as to the effects'. ${ }^{25}$ This also includes consideration of protective measures directed at avoiding or reducing any direct effects on the site, ${ }^{26}$ whereas 'compensatory measures' cannot be considered under Article 6(3). ${ }^{27}$ The CJEU has further dealt with the question whether positive effects of 'conservation measures' (Art. 6(1)) and 'preventive measures' (Art. 6(2)) may be taken into account under Art. 6(3) in the PAS case, see below. ${ }^{28}$ An appropriate assessment must also consider the cumulative effects of all other projects or plans that, in combination with the project in question, are likely to have a significant effect on a protected site. This also includes existing projects or activities, even though these precede the date of transposition of the Habitats Directive. ${ }^{29}$ Finally, the crucial obligation of Article 6(3) is that projects (or plans) that may adversely affect the integrity of the site in question cannot be approved unless the derogation in Article 6(4)

22 CJEU Judgment: Case C-142/16 Commission v Germany [2017] ECLI:EU:C:2017:301, para. 29 regarding a German power plant located $600 \mathrm{~km}$ downstream from Natura 2000 areas designated for the protection of certain migratory fish species.

CJEU Judgment Case C-323/17 People Over Wind and Peter Sweetman v Coillte Teoranta [2018] ECLI:EU:C:2018:244, para. 40. The extent to which this ruling was based on a disagreement (or uncertainty) regarding the protective measures is not clear. However, the implications of the general statement by the Court may be wide-ranging, considering the delicate balance between the design of a project and protective (or mitigation) measures. Also see R. Broadbent \& C.A. Caine, A fresh start for screening under the Habitats Regulations: Case c-323/17 People Over Wind, Peter Sweetman v Coillte Teoranta [2018] Ecr I-244, Environmental Law Review 2018 (20), p. 163.

24 CJEU Judgment: Case C-127/02 Waddenzee [2004] ECLI:EU:C:2004:482, para. 54.

25 CJEU Judgment: Joined Cases C-387/15 and 388/15 Hilde Orleans and Others v Vlaams Gewest [2016] ECLI:EU:C:2016:583, para. 50.

26 CJEU Judgment: Case C-142/16 Commission v Germany [2017] ECLI:EU:C:2017:301, para. 34 .

27 CJEU Judgment: Case C-521/12 T.C. Briels and Others v Minister van Infrastructuur en Milieu [2014] ECLI:EU:C:2014:330, para. 29.Supra 9, para 123-125.

28 CJEU Judgment Joined Cases C 293/17 and C 294/17, supra n. 9, para. 123-125, 132.

29 CJEU Judgment: Case C-142/16 Commission v Germany [2017] ECLI:EU:C:2017:301, para. 61. However, in this case an application for a project that had no prospect of succeeding should not be considered. 
can be used. The CJEU has established a strict requirement for certainty, in the sense that 'no reasonable scientific doubt remains as to the absence of such effects. ${ }^{30}$ According to the CJEU, this implies that an appropriate assessment must 'guarantee beyond all reasonable doubt' that there will be no adverse effects on the integrity of the site. ${ }^{31}$

In the joined cases, $\mathrm{C}-293 / 17$ and $\mathrm{C}-294 / 17$ - the PAS case - regarding the Dutch regulation of nitrogen, the CJEU as mentioned above emphasised that only protective measures may be taken into account in the appropriate assessment and reiterated the requirement for certainty in relation to the programmatic approach (paras. 104, 112, 120). In line with previous rulings, ${ }^{32}$ the Court rejected taking into account (active) management measures or other (autonomous) measures which do not have the effect of preventing extra deposition and its negative effects on the habitats, but which will improve the habitats or otherwise have positive effects on the habitats. Such measures may be taken into consideration as compensatory measures and may also play a role when examining the conservation status, but may not be taken into account when assessing the effects of plans and projects on the basis of Article 6 (3) (para 123-125). However, the judgment is not crystal clear on this (important) point. Whereas the court in para 124 states that the positive effects of the necessary measures under Art. 6(1) and 6(2) of the Habitats Directive may not be invoked in the assessment under paragraph 3 of that article, it states in para. 132 that such measures may not be taken into account in an appropriate assessment 'if the expected benefits of those measures are not certain at the time of that assessment'. Unfortunately, both parts of the judgment seem to be contradictory. The Dutch Council of State has followed basically the more strict interpretation, but has tried to dissolve the contradiction by deciding that the effects of measures necessary under paragraphs 1 and 2 of Art. 6 may not be taken into account to outbalance negative effects of plans or projects, even if

30 CJEU Judgment: Case C-127/o2 Waddenzee [2004] ECLI:EU:C:2004:482, para. 59. Also see C-258/11 Sweetman [2018] ECLI:EU:C:2018:244, para. 43 setting up a requirement of no risk of lasting harm to the ecological characteristics of a site.

CJEU Judgment: Case C-142/16 Commission v Germany [2017] ECLI:EU:C:2017:301, para. 38. In this case, the Court case rejected an impact assessment that did not include any definitive data on the effects of a fish ladder, but merely stated that its effectiveness could be confirmed only following several years of monitoring cf. para. 37. Such monitoring could not be considered sufficient to ensure fulfilment of the obligations in Article 6(3) c.f. para. 43 .

32 Most notably CJEU Judgment: Case C-521/12 Briels [2014] ECLI:EU:C:2014:330 and CJEU Judgment: Case C-387/15 Orleans [2016] ECLI:EU:C:2016:583 rejecting the use of compensatory measures under Article 6(3). 
the positive effects of such measures are certain. However, such effects may, if they are certain, be taken into account when examining the conservation status, which for example is necessary within Art. 6(4) of the Habitats Directive. ${ }^{33}$ As also this interpretation is not fully convincing it will be interesting to follow the discussions and judicial decisions on this point in other member states.

Nevertheless, it appears that the Court of Justice has acknowledged the relevance of a programmatic approach, including its potential to 'examine better the cumulative effects of various projects' at a programmatic level (para. 97). Also, the Court accepted that thresholds could be used to exclude projects from individual permit requirements - again, contingent on their meeting the criterion that there is no reasonable scientific doubt as to the lack of adverse effects of those plans or projects on the integrity of the sites concerned (para. 112).

A crucial question is how the certainty requirement can be met, given the many uncertainties of the ecological fact-finding and prognoses, and whether, in practice, this leaves any room for a programmatic approach. On the other hand, one may ask whether a project approach actually ensures a greater degree of certainty, particularly considering uncertainties associated with the potential effects of individual agricultural activities. These questions will be discussed in section 4, following a comparative account of ammonia regulation of agricultural activities in Denmark, Germany and the Netherlands.

\section{Regulating Agricultural Ammonia Emissions in Denmark, Germany and the Netherlands}

From an international and EU perspective, the regulation of agricultural ammonia emissions stands on two pillars. One is based on the 1999 Gothenburg Protocol to the Convention on Long-Range Transboundary Air Pollution ${ }^{34}$ and the NEC and NERC Directives. ${ }^{35}$ This legal regime is based on reduction targets

33 Council of State, Administrative Jurisdiction Division, 29 May 2019, ECLI:NL:RVS:2019:1603, para 11-14, more especially 11.4.

34 United Nations Treaty Series, vol. 2319 p. 81.

35 Directive 2001/81/EC of the European Parliament and of the Council of 23 October 2001 on national emission ceilings for certain atmospheric pollutants (NEC Directive) OJ 2001 L 309/22 was repealed by 1st July 2018 by Directive (EU) 2016/2284 of the European Parliament and of the Council of 14 December 2016 on the reduction of national emissions of certain atmospheric pollutants, OJ 2016 L 344/1, (NERC Directive). 
for ammonia emissions and other air pollutants, and appropriate measures should be established accordingly. ${ }^{36}$ The other pillar is constituted by the Bern Convention, the EU Birds Directive, and in particular, the EU Habitats Directive. As discussed above, the latter establishes a strict regime directed at both redressing and avoiding adverse effects on Natura 2000 sites, to protect certain species and habitats. The framework of the EU Nitrates Directive also indirectly - addresses ammonia emissions through its regulation of nitrate emissions from agricultural practices. However, this article will not elaborate on this. ${ }^{37}$ Although air pollution legislation is likely to play out as general legal standards for emission reductions, nature protection legislation presupposes site-specific regulatory measures that are not only directed at reducing or avoiding emissions, but also at addressing their adverse effects on habitat types and species, with the purpose of achieving environmental objectives or a favourable conservation status. The latter may entail general standards as well as individual assessment and permit procedures, possibly combined with (pro)active management measures.

Ammonia regulation is often characterised by a combination of various regulatory measures that seek to meet the requirements of air pollution legislation as well as nature protection legislation. ${ }^{38}$ However, in the following sections we focus on how the legal frameworks seek to meet the requirements of the Habitats Directive. First, we provide a brief overview of ammonia regulation in the three countries discussed here, then we examine the implementation of Article 6(3) with respect to agricultural ammonia emissions, in greater detail.

\subsection{Overview of Agricultural Ammonia Regulation}

Denmark, Germany and the Netherlands have approached agricultural ammonia regulation rather differently, despite having a relatively similar starting point with regard to ammonia emissions from agriculture. Whereas Denmark and the Netherlands have had specific legislation concerning agricultural

36 According to the NEC/NECR Directive, the reduction targets for 2020 and 2030, compared to 2005 levels, are: $24 \%$ in Denmark (2020/2030); $5 \%$ (2020) and $29 \%$ (2030) in Germany; $13 \%(2020)$ and $21 \%(2030)$ in the Netherlands.

37 For example, see $A$. M. Keessen et al. The Need for Flexibility and Differentiation in the Protection of Vulnerable Areas in EU Environmental Law: The Implementation of the Nitrates Directive in the Netherlands. JEEPL 2011 (2) p. 141, and H.T. Anker, Agricultural nitrate pollution - regulatory approaches in the EU and Denmark. Nordic Environmental Law Journal 2015 (2) p. 7.

38 See H. T. Anker et al., Comparison of ammonia regulation in Germany, the Netherlands and Denmark - legal framework, 2018, Copenhagen University, IFRO Report Series 276. 
ammonia emissions for several years, Germany has developed specific legislation only recently. Yet Germany and Denmark share a more traditional legal approach that focuses on individual assessment and permit requirements for livestock installations, whereas the Netherlands has taken a more novel approach that involves various policy instruments, combined with a preference for applying general standards. In Denmark, the individual assessments have been standardised to a great extent, even with regard to considering possible cumulative effects. In all three countries, certain technology-based standards have been imposed with regard to livestock installations. However, there are differences in whether such standards are imposed as general requirements - as in the Netherlands - or as conditions for permitting livestock installations, as in Denmark and Germany. What also differs is the extent to which, and when such standards apply to existing installations. ${ }^{39}$

In Denmark, an Ammonia Action Plan was presented in 2001 with the goal of reaching the 2010 reduction target in accordance with the Gothenburg Protocol and to protect Natura 2000 sites. ${ }^{40}$ It identified several measures related to livestock installations, manure storage, manure spreading and so forth, which were subsequently incorporated into legislation. In 2007, a new Act on Environmental Permits for Livestock Installations ${ }^{41}$ was adopted, which introduced two different sets of buffer-zone requirements regarding nitrogen sensitive habitats. A general ammonia emission reduction requirement for new or amended livestock installations was also introduced. In 2011 the ammonia regulation in the Act on Environmental Permits for Livestock Installations was replaced by a set of new rules that combined the general ammonia emission reduction requirement with more specific total ammonia thresholds to be applied through the permit procedures for establishing or amendment of livestock installations. Manure spreading is subject to general standards, however stricter standards apply in proximity to certain sensitive habitats in Natura 2000 sites. Moreover, significant changes in manure spreading practices in $\mathrm{Na}$ tura 2000 sites require prior notification and acceptance by the authorities according to the Nature Protection Act. ${ }^{42}$

39 Id. at p. 3.

40 Ministry for Food, Agriculture and Fisheries and Ministry for Environment and Energy, Handlingsplan til reduktion af ammoniakfordampningen fra landbruget, 2001.

41 Act no. 1572/2006 (lov om miljøgodkendelse af husdyrbrug), now Consolidated Act no. 5 20/2019 on livestock installations and the spreading of manure (lov om husdyrbrug og anvendelse af gødning m.v.). For further information on the act see J. Kauppila \& H.T. Anker, The Role of Permits in Regulating Livestock Installations and Manure Spreading: Experiences from Denmark and Finland. European Energy and Environmental Law Review 2018 (3), p. 88.

Consolidated Act no. 240/2019 on nature protection (lov om naturbeskyttelse). 
In Germany, some ammonia emission requirements were specified in the federal Technical Guidelines for the Prevention of Air Pollution (TA Luft 2002). ${ }^{43} \mathrm{TA}$ Luft is an administrative regulation that is applied through permit procedures by the competent authorities, and it also specifies legal obligations for installations that do not require an environmental permit, but are subject to the Bundesimmissionsschutzgesetz (BImSchG). ${ }^{44}$ Thus, TA Luft includes obligations that are binding internally on the authorities in their administration of the legislation. Some Länder have adopted their own administrative regulations, including Schleswig-Holstein, which adopted a so-called 'Filter Decree' in 2014. ${ }^{45}$ A proposal for a new TA Luft $(2018)^{46}$ has been put forward that is based on the ammonia thresholds and criteria regarding Natura 2000 sites developed through the decisions of the German courts and administrative technical convention (Fachkonventionen), which should reflect the best technical and scientific knowledge (see 3.2.2). Manure and fertiliser spreading are subject to the general fertiliser law, which has no special regulations for the protection of Natura 2000 sites. ${ }^{47}$ In June 2018, the CJEU ruled that Germany was in breach of the Nitrates Directive. ${ }^{48}$ This decision referred to the legal situation in 2016. However, the ruling is also significant for the 2017 fertiliser law, as the amendment retained several of the regulatory concepts and regulations

43 Erste Allgemeine Verwaltungsvorschrift zum Bundes-Immissionsschutzgesetz „Technische Anleitung zur Reinhaltung der Luft - TA Luft“ of 24 July 2002, officially published in Joint Ministerial Bulletin of 30 July 2002 (GMBl. 2002, Issue 25-29, p. 511-605). Download at https://www.bmu.de/fileadmin/Daten_BMU/Download_PDF/Luft/taluft.pdf.

44 Gesetz zum Schutz vor schädlichen Umwelteinwirkungen durch Luftverunreinigungen, Geräusche, Erschütterungen und ähnliche Vorgänge (Act on the Prevention of Harmful Effects on the Environment Caused by Air Pollution, Noise, Vibration and Similar Phenomena) in the version published on 17 May 2013) (в ввl. I p. 1274 et sqq.), last amended by Article 1 of the Law of 8 April 2019 (вGBl. I p. 432 et sqq.). An older English edition is available under https://www.bmu.de/fileadmin/Daten_BMU/Download_PDF/Luft/ bimschg_en_bf.pdf.

45 Ministerium für Energiewende, Landwirtschaft, Umwelt und ländliche Räume, Immissionsschutzrechtliche Anforderungen an Tierhaltungsanlagen und an Anlagen zur Lagerung von Gülle, decree from 26 June 2014, OJ SH 2014, p. 523 et sqq.

46 Draft of 16 July 2018 „Entwurf zur Neufassung der Ersten Allgemeinen Verwaltungsvorschrift zum Bundes-Immissionsschutzgesetz Technische Anleitung zur Reinhaltung der Luft“, https://www.bmu.de/gesetz/entwurf-zur-neufassung-der-ersten-allgemeinenverwaltungsvorschrift-zum-bundes-immissionsschutzgeset/.

47 The Fertiliser Act (DüngG) and the Fertilisers Ordinance (DüV) as action programmes for the whole of Germany in accordance with Article 5 Nitrates Directive.

C-543/16 Commission v Germany. 
criticised by the Court, ${ }^{49}$ which is why the Commission continues to regard the Nitrates Directive as infringed. ${ }^{50}$

In the Netherlands, agricultural ammonia regulation is based mainly on the Livestock and Ammonia Act (2002) and the Decree on Low Emission Stables (2013/2015), ${ }^{51}$ which impose general distance requirements (buffer zones), rules on manure spreading that conform with the Nitrates Directive, and other emission-reduction measures for livestock installations. Between 2000 and 2014, spatial planning was used to concentrate intensive livestock farming. The Reconstruction Act (repealed in 2014) restricted the establishment and expansion of livestock farms near Natura 2000 sites, and allowed for establishment and expansion in so-called 'concentration areas. ${ }^{52}$ Recently, attempts were made to reduce the number of livestock animals in the Netherlands through phosphate and production rights. ${ }^{53}$

Whilst the acts mentioned above first and foremost concern environmental aspects and spatial planning, nature protection law has introduced particular, specific nitrogen regulation. The so-called 'PAS' was adopted in 2015. Briefly, the PAS system seeked to address the assessment requirements of the Habitats Directive Article 6(3) at a 'programmatic' level, considering general reduction measures and trends, as well as (planned) nature management and restoration measures intended to stabilise and ultimately improve the conservation status of Natura 2000 sites. For each Natura 2000 site, there was an assessment of the current status, the current and permitted activities, general reduction trends and additional restoration measures. Whether and how much 'room for further development' would be available for issuing subsequent permits

49 For details, see $S$. Möckel, Germany's excessive agricultural nitrogen emissions and the need to improve existing regulatory concepts, JEEPL 2019, 281-305.

5o F. Schulz, Groundwater: Nitrate pollution will continue to be an issue across generations, euractive.com, 25.3.2019.

$5^{1}$ Wet Ammoniak en veehouderij (Livestock and Ammonia Act), Besluit emissiearme huisvesting (Decree on Low Emission Stables). The consolidated versions of all Dutch acts can be found at www.wetten.overheid.nl.

52 Reconstructiewet Concentratiegebieden (Reconstruction Act). See W. J. E. van der Werft, Jurisprudentie Reconstructiewet concentratiegebieden, Land en Tuinbouw Bulletin 2007(4), p. 10.

53 These rights are based on the (revised) Fertilisers Act, i.e. the Meststoffenwet. The phosphate rights are primarily directed at ensuring compliance with the EU Nitrates Directive, but will also reduce ammonia emissions. They impose a reduction on the number of cattle in the Netherlands. Also see H. A. Verbakel-Van Bommel, Overgang van fosfaatrechten; de Meststoffenwet, Tijdschrift voor Agrarisch Recht 2018 (10), p. 493. D. W. Bruil, Onder het fosfaatplafond!, Tijdschrift voor Agrarisch Recht 2017(3), p. 99. 
was calculated, given the need to demonstrate that the programme as a whole needed to ensure that there are no significant detrimental effects on Natura 2000 sites.

In the following sections we focus on the assessment and permit requirements for new and amended livestock installations, with regard to Article 6(3) of the Habitats Directive. Compliance with the Habitats Directive, particularly in view of the PAS case, is discussed in section 4 .

\subsection{Implementing Article 6(3)}

Before going into detail on the screening, assessment and permit requirements for Article 6(3) in Denmark, Germany and the Netherlands, it should be noted that these requirements must be seen in light of the Article 6(1) obligation to maintain or achieve a favourable conservation status. First, it is important to determine whether a favourable conservation status for habitats and species is to be achieved at site level or at the national level. In this respect, the Netherlands gained the European Commission's acceptance of a strategy whereby favourable conservation status is achieved at the national level, and not necessarily at each site. The CJEU has at least indirectly expressed the view that a favourable conservation status does not necessarily have to be achieved at the individual site level, but may be achieved at national level. ${ }^{54}$ This may in some circumstances give the Member States the flexibility to focus on sites that are less exposed to nitrogen deposition for initiating active management measures and achieving a favourable conservation status in the country as a whole. However, in all areas, compliance with the no-deterioration obligation of Article 6(2) will serve as the minimum requirement, subject to the possible exception of Article 6(4). Second, the role of adequate management or restoration measures is important for both achieving a favourable conservation status, and with regard to the no-deterioration obligation. Although CJEU case law is limited when it comes to Member States' actual obligations to initiate management measures, the CJEU has clearly rejected the use of management measures intended to compensate adverse effects, under Article 6(3), as opposed to mitigation measures intended to avoid or partly avoid adverse effects. ${ }^{55}$ Nevertheless, the management measures and the regulation of existing activities, such as restrictions on existing livestock installations, play a crucial role in achieving a favourable status for nutrient-sensitive habitats.

54 CJEU Judgment: Case C-281/16 Vereniging Hoekschewaards Landschap v Staatssecretaris van Economische Zaken, ECLI:EU:C:2017:774, para. 36 .

55 CJEU Judgment: Case C-521/12 T.C. Briels and others, ECLI:EU:C:2014:330, para. 31. 
In Denmark, Germany and the Netherlands, identifying both the objectives, that is, favourable conservation status and the relevant management measures, appear to be dealt with primarily by Natura 2000 management plans, including management or restoration measures related to eutrophication by airborne nitrogen deposition. Examples of management measures that contribute to improving the conservation status of nitrogen sensitive habitats are extracting nitrogen by removing sods or shrubbery, or optimising the hydrological conditions in a Natura 2000 site. Natura 2000 management plans are mandatory in Denmark and the Netherlands, whereas in Germany the Länder have the option of prescribing the adoption of management plans. Management plans may include permissions for concrete plans or projects, and therefore may have a regulatory function in both the Netherlands and Germany, whereas this is not the case in Denmark. The regulation of livestock installations is not part of the Danish Natura 2000 management plans, as this is regulated by the Livestock Installations Act. In the Netherlands, the development of the PAS system has influenced the Natura 2000 management plans, and they were integrated into the PAS system, and its management and restoration activities. Although the existence and content of Natura 2000 management plans may vary among the German Länder the designation decision (by the Länder) may also include provisions regarding both new and ongoing activities. In general, however, neither the designation acts nor the management plans include provisions or measures related to livestock installations in Germany.

\subsubsection{Project Definition}

Determining which projects are subject to examination under Article 6(3) varies in Denmark, Germany and the Netherlands. In this section we focus on how the legal frameworks in these countries ensure that all relevant projects are considered under Article 6(3), and also how such projects are delimited, including whether manure-spreading and grazing are considered parts of a livestock installation project, or a separate project.

In all three countries under discussion, livestock installations are subject to various environmental permit or authorisation requirements. ${ }^{56}$ Denmark has the most extensive environmental permit scheme, as establishing or amending livestock installations with production areas greater than $100 \mathrm{~m}^{2}$ are subject to an environmental permit requirement under the Livestock Installations Act. Large pig and poultry installations that exceed the thresholds of the Industrial

$5^{6} \quad$ Anker et.al. supra n. $3^{8}$ at pp. $13^{-15}$. 
Emissions Directive (IED), 57 and other installations with ammonia emissions above $3500 \mathrm{~kg} \mathrm{~N} /$ year have more comprehensive permit requirements. In Germany, the BImSchG requires a regular permit for livestock installations that exceed the IED thresholds, and a simplified permit for other livestock installations that exceed certain thresholds. Installations that fall below these thresholds generally require a building permit, and in some cases, also water permits. In the Netherlands, environmental permits apply only to pig and poultry installations that exceed the IED thresholds. However, Article 6 (3) Habitats Directive is transposed into the Dutch Nature Protection Act, ${ }^{58}$ which generally requires that all projects which may affect a Natura 2000 site need a permit and are subject to a Natura 2000 assessment, including smaller livestock installations.

In Denmark and Germany, the screening and assessment requirements of Article 6(3) of the Habitats Directive are integrated with the permit procedures. In the Netherlands, a separate Natura 2000 screening, assessment and permit requirement applies to livestock installations, according to the Nature Protection Act. However, this separate permit has been linked to the PAS system (further discussed below).

In general, grazing and manure spreading are not included in the permit systems for livestock installations in Denmark, Germany or the Netherlands. In all three countries, spreading manure and other organic fertilisers is subject to general standards regarding spreading methods, such as injection or incorporation. ${ }^{59}$ In Denmark, the spreading of manure was included in the livestock installation permits until February 2017, but is now subject to separate legislation, in the form of general, but differentiated standards regarding nitrogen and phosphorus. Moreover, significant changes in manure spreading, particularly a shift from inorganic fertilisers to manure, may be considered a project in itself, and is subject to a Natura 2000 notification requirement, under the Nature Protection Act. Generally, in Germany, agricultural land use (e.g. fertilising, ploughing, pesticide use) does not require a permit. If agricultural activities classify as a project with regards to a Natura 2000 area, the nature conservation authorities must be notified about such farming measures, pursuant to Article 34 (6) of the Federal Nature Conservation

57 Directive 2010/75/EU of the European Parliament and of the Council of 24 November 2010 on industrial emissions (integrated pollution prevention and control), OJ L 334, 17.12.2010, p. 17-119.

$5^{8}$ Wet Natuurbescherming (Nature Protection Act).

59 Anker et al. supra, n. 38 , at p. 23. 
Act. ${ }^{60}$ If the authority does not determine Natura 2000 compatibility within one month, the project may be started. In the Netherlands, grazing (and changes in manure spreading) did not fall within the scope of the permit requirements for projects under the Nature Protection Act, as, until recently, they were deemed not to be projects. However, the Council of State doubted whether this is in accordance with the Habitats Directive in all circumstances. The CJEU's 2018 judgment made clear that grazing and manuring may qualify as projects, and therefore, if they may have a significant effect on an area, must be assessed in conformity with the Article 6(3) Habitats Directive. ${ }^{61}$ In line with the CJEU ruling, the Council of State ordered that these practices cannot remain unlicensed in principle and in all cases, because it is, at least in some cases, uncertain beforehand whether they will have significant negative effects. ${ }^{62}$

\subsubsection{Determining 'Significant Effects' and Using Thresholds}

Determining potential significant effects under Article 6(3) faces significant challenges in all three countries discussed here, and different approaches have been chosen when assessing the potential effects of new or amended livestock installations. All three countries have perceived a need to standardise the assessment of potential adverse effects of ammonia depositions on habitats in Natura 2000 sites that are sensitive to nitrogen deposition, but to some extent also with regard to other nitrogen sensitive habitats, through the use of thresholds. Such thresholds may be used as part of (preliminary) screening for significant effects, in an appropriate assessment or as a threshold to determine whether or not to grant a permit. Therefore, such thresholds may fulfil different legal functions, and some degree of caution should be used when comparing such thresholds.

In Denmark, the Livestock Installations Act (and Executive Order 718/2019) establishes a standardised assessment with respect to 'ammonia sensitive' habitats, including habitats within Natura 2000 sites - so-called 'category 1 habitats'. Forty-three of the fifty-nine habitat types in Denmark are category 1 habitats. According to the Livestock Installations Act, there are specific permit

6o Gesetz über Naturschutz und Landschaftspflege (Bundesnaturschutzgesetz - BNatSchG) of 29 July 2009 (BGBl. I p. 2542), as last amended by Article 8 of the Act of 13 May 2019 (вGBl. I p. 706). An older English edition is available under http://www.bmub.bund.de/ fileadmin/Daten_BMU/Download_PDF/Naturschutz/bnatschg_en_bf.pdf.

61 Joined Cases C 293/17 and C 294/17, para 73.

62 Council of State, Administrative Jurisdiction Division, 29 May 2019, ECLI:NL:RVS:2019:1604, Administratiefrechtelijke Beslissingen (AB) 2019, 308, with casenote Backes. 
thresholds for livestock installations that are established or amended in the vicinity to category 1 habitats. The category 1 criteria apply to the calculated total load, that is, the ammonia deposition from the new/amended installation and from the already-existing installation. Cumulative effects from nearby livestock installations must also be considered. This is done in a standardised way. For a permit to be granted, the maximum allowable deposition in a category 1 habitat is $0.7 \mathrm{~kg} \mathrm{~N} / \mathrm{ha} /$ year, if there are no other farms nearby; $0.4 \mathrm{~kg} \mathrm{~N} /$ ha/year if there is one other farm in the vicinity; and $0.2 \mathrm{~kg} \mathrm{~N} / \mathrm{ha} /$ year if there is more than one other farm in the vicinity. In addition to the specified category 1 habitats it cannot be ruled out that the effects on other sensitive habitat types or Annex IV species must be assessed on an individual basis in the permit procedure, cf. Executive Order 1595/2018.63 Although the standardised assessment does not take into account the site-specific conditions, for example, sitespecific critical loads, it does consider cumulative effects from other livestock installations.

In Germany, the Federal Administrative Court (BVerwG) accepted specific criteria for assessing possible significant effects on the integrity of Natura 2000 sites. ${ }^{64}$ In the absence of legally-defined thresholds for pressure, the German authorities and courts refer to the critical loads for a given habitat type or protected species. ${ }^{65}$ They also established thresholds for bagatelles or irrelevance, differentiating between cut-off criteria and de minimis thresholds. In addition to cut-off criteria and de minimis thresholds for land losses, ${ }^{66}$ the BVerwG also recognised general thresholds of bagatelles for nitrogen input, with a cut-off

63 See further H. T. Anker \& L. Baaner, National report on the legal framework for ammonia regulation of livestock installations with a particular regard to Natura 2000 sites: Denmark, 2018, Department of Food and Resource Economics, University of Copenhagen. IFRO Report No. 275, p. 14.

64 S. Möckel, The assessment of significant effects on the integrity of 'Natura 200o' sites under Articles 6(2) and 6(3) of the Habitats Directive, Nature Conservation 2017, p. 57-86.

65 BVerwG, Judgment of 17 January 2007 - 9 A 20.05, BVerwGE 128, 1 marg. 48; Decision of 5 September 2012 - 7 B 24.12, marg. 7 ff.; Judgment of 29 September 2011 - 7 C 21.09, marg. 41 und Ls. 4; Judgement of 6 November 2012 -9 A 17.11, marg. 93 with further references. $S$. Balla et al., Untersuchung und Bewertung von straßenverkehrsbedingten Nährstoffeinträgen in empfindliche Biotope - Bericht zum FE-Vorhaben 84.0102/2009 der Bundesanstalt für Straßenwesen, Bundesanstalt für Straßenwesen, Forschung Straßenbau und Straßenverkehrstechnik Band Bd. 1099, Bremen, pp. 123 et seq.

66 BVerwG, Judgment of 28 March 2013 - 9 A 22.11, BVerwGE 146, 145 marg. 40 et seq.; Judgment of 13 May 2009 - 9 A 73.07, NuR 2009, 711, marg. 49; Judgement of 12 March 2008 - 9 A 3.06, BVerwGE 130, 299, marg. 125 et seq.; H. Lambrecht and J. Trautner, Fachinformationssystem und Fachkonventionen zur Bestimmung der Erheblichkeit im Rahmen der FFH-VP, Bonn - http://www.bfn.de/fileadmin/MDB/documents/themen/ 
criterion of $0.3 \mathrm{~kg} \mathrm{~N}$ per hectare per year, and a de minimis threshold of three per cent of a critical load. ${ }^{67}$ The cut-off criterion of $0.3 \mathrm{~kg} \mathrm{~N} / \mathrm{ha} /$ year is a threshold for the emissions of a project or plan, whereas the de minimis threshold of $3 \%$ of the critical load of a habitat type or a species is a threshold for the emissions from the project, combined with other plans or projects. In practice, this means that in relation to ammonia emissions, no further appropriate assessment is necessary, if the screening step ascertains that the cut-off criterion will not be exceeded by the project, or the de minimis threshold will not be exceeded by the project in combination with other plans or projects.

In the Netherlands, the approach to addressing additional $\mathrm{N}$-depositions in Natura 2000 areas was very strict before July 2015. According to the Administrative Jurisdiction Division of the Council of State, any additional deposition, even an additional deposition of only $0.01 \mathrm{~kg} / \mathrm{ha} /$ year, caused by a plan or project, which leads to, or further aggravates an exceedance of the critical loads of a habitat type in a protected area, leads to the conclusion that the project or plan may have significant effects for the conservation aims and that an appropriate assessment is needed. The courts did not accept any threshold. However, since July 2015, the PAS system applied. The PAS system determined relevant screening and permit thresholds for ammonia emissions related to the 118 Natura 2000 sites identified as 'nitrogen sensitive'. According to the PAS, no permit was needed for existing activities, such as livestock installations, and for new projects with ammonia emissions that result in an additional, modelbased theoretical deposition below $1 \mathrm{~mol} \mathrm{~N} / \mathrm{ha} /$ year $(0.014 \mathrm{~kg} \mathrm{~N} / \mathrm{ha} /$ year) in a sensitive habitat. Such projects only had to be reported. If the deposition was below $0.05 \mathrm{~mol} \mathrm{~N} / \mathrm{ha} /$ year), there even was no requirement to report. All such projects were authorised through the PAS programme, based on appropriate assessments for each area of all existing depositions, the (cumulative) effects of future activities that add no more than $1 \mathrm{~mol} \mathrm{~N} / \mathrm{ha} /$ year, and the effect of expected deposition reductions and restoration measures. Only new projects with ammonia emissions resulting in an additional calculated deposition above $1 \mathrm{~mol} \mathrm{~N} /$ ha/year still needed a permit (and Natura 2000 assessment), in accordance with the Nature Protection Act 2017. They could obtain a nature

natura200o/bfn-fue_ffh-fkv_bericht_und_anhang_juni_2007.zip, Bundesamt für Naturschutz, 2007, pp. 33 et seq., 43 et seq.

67 BVerwG, Judgment of 8 January 2014 - 9 A 4.13, marg. 69; Judgement of 23 April 2014 - 9 A 25.12, marg. 45 et seq. with further references and Ls. 1; Judgement of 6 November $2012-9$ A 17.11, marg. 62 and Ls. 3; Judgment of 29 September $2011-7$ C 21.09, marg. 42. Balla et al. supra n. 65 , pp. 94 et seq., 211 et seq.; 216 et seq. 
permit if there (still) was some 'room for further development' in or near the Natura 2000 site. If $95 \%$ or more of the 'room for development' had been used, the cut-off threshold for not needing a permit was lowered to $0.05 \mathrm{~mol} \mathrm{~N} / \mathrm{ha} /$ year ( $0.0007 \mathrm{~kg} \mathrm{~N} / \mathrm{ha} /$ year). Although these cut-off thresholds were very strict - and rather theoretical - it must be kept in mind that they relate to the additional load from the project in question, and to the question of whether or not a permit is needed. As the Council of State ruled that the PAS is not in accordance with the requirements of Article 6 Habitats Directive, it cannot be applied anymore. At the moment of finishing this contribution, the former, very strict approach of the Dutch courts applies again. If a project causes any additional deposition, even if this is less than $0,1 \mathrm{~mol}$, on a site in which the critical nitrogen loads are exceeded, an appropriate assessment is needed and it has to be proven that the additional deposition, in combination with the existing deposition, will not have any detrimental effect on the conservation objectives of the site. This has, led to a, at least temporarily, blockage for many projects like (enlargements of) motorways, airports or farms. ${ }^{68}$

\subsubsection{A Programmatic Approach}

As discussed above, Denmark, Germany and the Netherlands perceived a need to standardise the assessment of individual (livestock installation) projects, or perhaps even to adopt a programmatic approach. Put simply, a programmatic approach employs an appropriate assessment at a level above (or a more aggregate level than) individual project level. On the one hand this makes it possible to take into account the cumulative effects of all existing, proposed and expected activities causing e.g. nitrogen emissions. On the other hand measures which reduce or counterbalance e.g. nitrogen emissions and deposition can be taken into account. The Dutch PAS called the latter kind of measures 'management- and conservation-measures'. The - expected - positive effects of the measures and the - expected - cumulative emissions/deposition can then be balanced. This balance made for each area was the core element of the appropriate assessment of the PAS. The PAS measures included changes in the feeding of animals or modernising the vehicle fleet as well as measures which improve the hydrological conditions of certain habitats and make them more resilient, or measures which remove nitrogen from the area, like cutting sods or removing shrubbery. As long as the assessment, based on the balance of measures and cumulative effects of plans, projects and the existing situation,

68 See the judgments of the Council of State, Administrative Jurisdiction Division of 17 July 2019, for example ECLI:nl:RVs:2019:2466. 
demonstrates that the conservation status of the habitats concerned will improve (in the long run) or will at least not worsen, all plans and projects which were taken into account in the balancing process could be allowed without any additional appropriate assessment. The Dutch PAS system was an advanced and comprehensive example of a programmatic approach. It prescribed an assessment for each Natura 2000 site with the double purpose to achieve both a favourable conservation status and allow economic growth by determining the 'room for development' for each site.

The Dutch programmatic approach implied that all measures mentioned above, including management and conservation measures, as well as the autonomous development of the deposition level as a whole, were considered in an Article 6 (3) assessment. According the CJEU's rulings however, this is not allowed as, in terms of Article 6, neither 'conservation measures' within the meaning of paragraph 1 of Article 6, nor 'preventive measures' within the meaning of paragraph 2 may be taken into account in the appropriate assessment of Article 6 (3). These kind of measures are not 'protective measures forming part of the plan or project at issue and intended to avoid or reduce any direct adverse effects caused by it' and hence do not mitigate the negative effect of projects. ${ }^{69}$

The only measures which can be taken into account when assessing the effects of plans and programmes are measures which intend to reduce the negative effect of such plans and projects, for example by reducing the extra deposition of such projects or by reducing, in connection with a project, the current deposition of other activities. However, the effects of such mitigating measures may be considered only if it is sufficiently certain that they will effectively contribute to avoiding harm to the integrity of the site concerned, by guaranteeing beyond all reasonable doubt that the plan or project at issue will not adversely affect the integrity of that site..$^{70}$ The Council of State concluded that many of the mitigating measures of the PAS did not meet this requirement. ${ }^{71}$

The German authorities (and courts) also consider the positive effects of future measures, if they seem to be sufficiently certain. By contrast, in Denmark, the Article 6(3) assessment of livestock installations does not include the potential or achieved positive effects of management measures.

\footnotetext{
69 Supra n. 4, para. 121-125.

$70 \quad$ Supra n. 4, para. 126.

71 Supra n. 5, para. 19.6.
} 
Regulating agricultural ammonia emissions presents several challenges related to compliance with Article 6(3) of the Habitats Directive and the quest for certainty reflected in the CJEU's rulings concerning the absence of adverse effects on the integrity of a Natura 2000 site. Determining the potential effects of agricultural ammonia emissions is a complex exercise considering the relatively small-scale nature of most projects, a significant background load from various sources and the uncertainties in assessing the 'sensitivity' of different nature types and species.

Article 6(3) of the Habitats Directive relies on a traditional legal 'project approach', where individual projects (and plans) with a potentially significant effect are subject to an appropriate assessment and may be permitted only under certain circumstances. In view of the CJEU's rulings, three partly interrelated challenges, will be discussed in this section. The first challenge is how to ensure that all relevant agricultural projects are considered under Article 6(3), at least in the form of a screening to determine whether or not an appropriate assessment is needed. A second challenge concerns the extent to which thresholds or limit values may be used to exclude projects from the assessment or permit requirements, and in particular the relationship between the additional load (from the project in question), the total load (from the entire installation) and the cumulative load (from other projects). A third challenge relates to the options for a more programmatic and integrated approach, as reflected in the Dutch PAs system.

\subsection{Projects}

Regarding the first of the above-mentioned challenges, the 'project approach' noted in Article 6(3) implies some kind of permit, authorisation or notification procedure for projects, to ensure that it has been ascertained that the project will not result in adverse effects on the integrity of the site. Agricultural emissions are generated not only by livestock installations, but also from spreading manure (or other organic fertilisers) or grazing livestock. Livestock installations range from small-scale farms to larger (industrial) production facilities. The potential impact is determined not only by the size of an installation, but also by the state of its facilities, for example, stables, and their proximity to, and the state of the protected habitats and species.

The scope of permit or authorisation procedures for livestock installations varies significantly among the three countries examined above. Two different approaches have appeared in the comparative study. One links Natura 2000 assessment to various permit procedures, as is the case in Denmark and 
Germany, whereas the other is to apply a separate Natura 2000 assessment and permit procedures, as in the Netherlands. However, in both cases the permit system must have a rather broad scope, to ensure that projects with a potential adverse effect will not escape Article 6(3).

In none of the countries considered here are the effects of spreading fertilisers or grazing livestock on Natura 2000 sites assessed as part of an assessment or permit procedure for livestock installations, even though that was the case in Denmark until 2017. In the PAS case, the CJEU stated that grazing cattle and the application of fertilisers in the vicinity of Natura 2000 sites may, at least under certain circumstances, be classified as a project under the Habitats Directive (C-293/17, para. 73), even though it may also be considered a recurring activity that has been authorised under national law before the entry into force of the Habitats Directive. In essence, application of fertilisers (and grazing) should be subject to assessment under Article 6(3) if - due to changes in location or conditions - they may have a significant effect on a protected site. This answer of the court will now have to be implemented in the member states.

In the Netherlands, the government has not made up its mind of how to proceed after the abolishing of the PAs. At the moment of writing, on 12 July 2019, an expert commission has been installed which will have to advise the government on possible solutions. ${ }^{72}$ Regarding grazing and manuring, a legal or administrative guidance on the question under which conditions grazing and (changes in) manuring must be qualified as projects may be an outcome. As described in section 3.2.2., a notification scheme such as the Danish scheme requires individual assessment of such projects. However, the question is whether the notification scheme is sufficiently broad to encompass all relevant changes in fertiliser or grazing practices. In Germany, the previous notification solution for farming measures not subject to authorisation (see 3.2.1) did not guarantee that all relevant measures would also be notified and subject to appropriate assessment by the authorities. ${ }^{73}$ In practice, hardly any farming measures - such as fertilising, or using pesticides - in or near Natura 2000 have been subject to appropriate assessment in Germany.

A comprehensive project approach to fertiliser application or grazing that requires permits or notification will be resource demanding given the CJEU's

72 See https://www.rijksoverheid.nl/documenten/publicaties/2019/07/12/leden-advies college-stikstofproblematiek.

73 S. Möckel, The terms 'project' and 'plan' in the Natura 2000 appropriate assessment, Nature Conservation, 2017, p. 31-56. 
certainty requirements. Another regulatory approach is the use of targeted standards that set specific requirements for the application of manure or grazing pressure in Natura 2000 sites or in the proximity to Natura 2000 sites and/or sensitive habitats, such as so-called 'buffer zones'. In Denmark, this is partly reflected in the general standards for manure application which prohibit certain spreading practices within $20 \mathrm{~m}$ from nitrogen sensitive habitat types. Such general standards must also be subject to an appropriate assessment under Article 6(3), as they must ensure that these activities do not have a significant detrimental effect on habitats and species. Thus, a project or permit approach to agricultural land use activities, such as fertiliser application or grazing, may not be the only - or the most effective - solution for ensuring a favourable status of habitats and species in Natura 2000 sites. Grazing and manuring may also be effectively considered under a programmatic approach. For each site, there would be an assessment of whether and to what extent grazing and manuring are possible without endangering the conservation objectives of the site concerned - possibly in combination with general standards applying in specific areas.

\subsection{Thresholds for Significant Effects}

The second challenge regarding agricultural ammonia regulation concerns the extent to which thresholds or limit values may be used to make the assessment of significant effects more feasible, and in some cases, also to exclude irrelevant projects from an appropriate assessment. According to the $\mathrm{CJEU}$, an appropriate assessment - and the application of Article 6 (3) - may be avoided only if it, on the basis of objective information, can be excluded that the project may have a significant effect (screening criteria). Similarly, the CJEU has stated that a permit can only be granted if there is no reasonable scientific doubt as to the absence of adverse effects (permit criteria). However, in the PAS case, the CJEU accepted the use of thresholds - as part of a programmatic approach - if the appropriate assessment 'meets the criterion that there is no reasonable scientific doubt as to the lack of adverse effects ... on the integrity of the site' (para. 112).

As described in section 3.2 the use of thresholds is prevalent in all three countries under discussion. However, the thresholds are not easily comparable, and their compliance with the requirements of the Habitats Directive remains debatable. One difference relates to the threshold level and the degree of certainty. Another difference relates to the question of additional load from the project in question -compared to the total load - from the entire livestock installation. Whereas the Dutch (and German) thresholds are based 
on the additional load from the project in question, the Danish thresholds are based on the total load from the entire livestock installation. From the wording of Article 6(3), it follows quite clearly that a project cannot be viewed in isolation when determining whether or not it may have a significant effect on a Natura 2000 site. Similarly, an appropriate assessment must also take into account how the effects of the project in question will interact with the effects from other projects or activities. Yet, this does not necessarily imply that the total load and/or cumulative effects determine whether or not a permit may be granted. Thus, the decisive point is whether the project in question, such as expanding a livestock installation, will affect the integrity of a Natura 2000 site. Although the potential effect should be viewed in combination with the initial load, including the load from the existing installation and cumulative effects, in principle a project that does not lead to an additional load would not affect the integrity of a site.

Whether a threshold, for example, the German cut-off threshold of $0.3 \mathrm{~kg}$ $\mathrm{N} /$ ha/year or Dutch PAS criterion of $0.014 \mathrm{~kg} \mathrm{~N} / \mathrm{ha} /$ year is acceptable may be debated. Following the CJEU's argument, it is necessary that it can be ascertained that an additional load below the threshold will in no circumstances combined with other effects be able to affect the integrity of the site. A cut-off threshold as such does not ensure this. Cut-off or de minimis criteria may be acceptable if they are combined with an assessment, either at site level or at programmatic level, which ensures that no negative effects will occur.

The Dutch screening criteria were set at a very low - and rather theoretical - level for an additional load from a project, that is, the expansion or amendment of a livestock installation, at $0.014 \mathrm{~kg} \mathrm{~N} / \mathrm{ha} / \mathrm{year}$ - or in some circumstances, as low as $0.0007 \mathrm{~kg} \mathrm{~N} / \mathrm{ha} /$ year (if $95 \%$ of the 'development room' has been used). An additional load of $0.014 \mathrm{~kg} \mathrm{~N} / \mathrm{ha} /$ year corresponds to less than $0.2 \mathrm{ml}$, a few drops of urine per $\mathrm{m}^{2} /$ year, probably less than a bird usually produces. It may be questioned whether it makes much sense to discuss that any load that is higher than this may be deemed to contribute to a significant adverse effect on the integrity of the habitats of a site. Whether such low - or theoretical - screening thresholds are in accordance with Article 6(3) depends on whether it is possible to ensure that such small additional depositions, taking all potential cumulative effects into account, will not cause any additional negative effects, under any circumstances. According to the opinion of G.A. Kokott in the PAS case, it was conceivable that the Dutch thresholds have a sufficient scientific basis to remove all reasonable scientific doubt (para. $105 \mathrm{ff}$ ).

The German thresholds are much higher, with the cut off criterion of an additional load of $0.3 \mathrm{~kg} \mathrm{~N} / \mathrm{ha} / \mathrm{year}$, and the cumulative de minimis threshold 
of $3 \%$ of the critical load of a habitat type or species (see 3.2.2). It is highly debatable whether the German thresholds are compatible with Article 6 (3) Habitats Directive, if they are not linked to a programmatic approach. ${ }^{74}$

As mentioned above, the Danish thresholds are different from the Dutch and German thresholds, as they refer to the total load from an entire livestock installation, as opposed to the additional load from the project in question. This means that even though a project expanding a livestock installation may result in a reduction of the total load (e.g. because new technology will be used), it is not possible to grant a permit if the threshold is exceeded. Nevertheless, one may question whether the thresholds of $0.2-0.7 \mathrm{~kg} \mathrm{~N} / \mathrm{ha} / \mathrm{year}$ meet the CJEU's certainty requirement. Another, perhaps more problematic aspect of the Danish thresholds is that they are not related to the actual state of the nitrogen sensitive habitats or species in question. The thresholds are based on what would generally fall below a detectable effect. Again, this makes it difficult to ascertain with certainty that there would be no adverse effects on the integrity of a specific site. Therefore, the Danish thresholds could be problematic in view of Article 6(3), unless it may be proven that the thresholds are established at a level that ensures that significant effects on all Danish Natura 2000 sites can be excluded.

In view of the CJEU's statements, the use of thresholds under Article 6(3) must be approached with some caution. It appears that acceptable thresholds for individual projects should be if not equal to, then at least almost equal to, 'no additional load'. This seems to be the case with regard to the Dutch thresholds. However, whether thresholds that reflect a detectable load - such as the German and Danish thresholds - may be used is questionable, considering not only the precautionary principle, but also the potential cumulative effects. Even if the additional calculated load is quite small, combined with an existing exceedance of the critical loads, such additional loads will, if realised, contribute to a possible significant negative effect on a site. However, such 'substantive' thresholds may be justifiable if they are combined with a programmatic approach.

\subsection{The Programmatic Approach}

Considering the uncertainties associated with the individual assessment of the potential effects of ammonia emissions from livestock installations, a third challenge relates to the options for a more integrated and programmatic approach, e.g. as reflected by the (now former) Dutch PAS system.

74 This is also mentioned by the AG in her conclusion on the PAS case: joined cases C-293/17 and C-294/17, ECLI:EU:C:2018:622, para. 108. Also see Möckel supra n. 49. 
The PAS system created 'room for development' for individual permits, based on the programmatic assessment of each Natura 2000 site, taking into account active management or restoration measures, combined with general ammonia emission reduction measures agreed upon at the national level. The programmatic approach addresses a perceived need to not view individual projects and permits in isolation if the aim is to achieve a favourable conservation status, or at least an improvement to the current - and often deplorable state - of many habitats, while not excluding the growth of economic activities.

An approach that mainly targets individual projects, such as livestock installations, may be feasible from a legal point of view, if screening and permit thresholds are based on a zero-additional-load from the project in question or possibly a load that has no detectable effect. This, however, does not ensure the achievement of a favourable conservation status, or even a halt in the further deterioration of nitrogen sensitive habitats. Even though Article 6(1) and 6(2) obliges the Member States to take action, the more precise scope of these obligations has not been elaborated and not much effort has been taken to comply with these obligations. A programmatic approach seems to be an appropriate option to apply meaningful thresholds that reduce the administrative burden for plans and projects resulting in a very limited amount of additional nitrogen deposition on Natura 2000 sites. Within a programmatic approach (the sum of) the effects of such plans and projects could be counterbalanced with measures to reduce the deposition on the areas or the amount of nitrogen in the area as long as these measures can be qualified as protective measures (or mitigating measures).

Before the CJEU's judgment in the PAS case, ${ }^{75}$ it was unclear whether Article 6(3) Habitats Directive required an assessment of each individual project, on its own or whether it was also possible to refer to an assessment of a more comprehensive programme that covered several projects, measures and other developments. The Advocate General concluded that, although an individual assessment of project is the 'guiding principle' of Article 6(3), an overall evaluation of all nitrogen deposition by some kind of programmatic approach 'is not only appropriate, but even necessary.... ${ }^{76}$ The CJEU did not go that far, but clearly accepted a programmatic approach, as this 'makes it possible to examine better the cumulative effects of various projects. ${ }^{7}$

75 Joined Cases C-293/17 and C-294/17, supra n. 4, paras 94-97.

76 Opinion of Advocate General Kokott on joined cases C-293/17 and C-294/17, ECLI: EU:C:2018:622, paras. 40-43.

77 Joined Cases C-293/17 and C-294/17, supra n. 4, para. 97. 
However, a programmatic approach must meet the same requirements as individual project assessments, insofar as 'a thorough and in-depth examination of the scientific soundness of that assessment makes it possible to ensure that there is no reasonable scientific doubt as to the absence of adverse effects of each plan or project on the integrity of the site concerned' (para. 104). In particular, the Court has noted that in circumstances ... where the conservation status of a habitat is unfavourable, the possibility of authorising activities which may subsequently affect the ecological situation of the sites seems necessarily limited' (para. 103). Our view is that it is extremely important that the Court, following the conclusion of the Advocate General, accepted the programmatic approach as such, although there is no explicit or even implicit legal basis for it in Article 6(3) Habitats Directive.

Compliance with the strict criteria for a programmatic approach that were established by the Court has turned out to be too challenging in the Netherlands, resulting in the (indirect) overturning of the PAs by the Dutch Council of State. ${ }^{78}$ One reason for this is that not only protective mitigating measures, but also conservation measures and preventive measures as well as the predicted autonomous development were taken into account in the balancing process. A second reason were the significant doubts about the effectiveness of at least of some of the management and conservation measures and other measures directed at reducing ammonia emissions, such as general technology standards that were prescribed and calculated in the Dutch PAs. ${ }^{79}$ As long as the PAS or any other programmatic approach or other form of (agricultural) policy does not ensure that, without any reasonable scientific doubt, nitrogen deposition on (all) Natura 2000 sites is constantly diminishing in the direction of the critical loads, it will be difficult to prove that actual additional depositions, in conjunction with the existing exceedance of the critical loads, will not have negative effects on the sites concerned. If it may be proven that the deposition is (constantly) declining, the question of the uncertainty concerning the vulnerability of species and habitat types, and the potential effects on them from several diffuse sources of pollution and of the effects of restoration and management measures become less vital. It remains to be seen how a declining trend of nitrogen deposition may be ensured, and whether a reduction in livestock numbers is avoidable.

78 Council of State 29 May 2019, ECLI:NL:Rvs:2019:1603.

79 According to the most recent monitoring results, many measures did not yet have a clear positive effect. The nitrogen emissions from the agricultural sector rose, rather than dropped, during the first three years of the PAs, cf. Tauw bv, Tussenevaluatie Programma Aanpak Stikstof, 2018, p. 6 ff. 
The state of many terrestrial Natura 2000 sites and habitats is inextricably linked to excessive ammonia emissions from agricultural activities. Yet, the regulation of agricultural ammonia emissions is not easily accomplished, as the Netherlands, Germany and Denmark have shown. To some extent, CJEU case law has accepted novel regulatory solutions such as a programmatic approach. At the same time, the Court's strict interpretation of Article 6(3) Habitats Directive limits the room to manoeuvre in all approaches. The Habitats Directive relies mainly on a traditional legal approach, based on individual assessment and permit requirements for projects. At best, such a traditional project approach serves to prevent additional pollution. However, for most Natura 2000 sites the main concern is to reduce existing levels of pollution, and initiate appropriate management and conservation or restoration measures. Moreover, the quest for certainty, as required by the CJEU in view of the precautionary principle, is difficult to meet with this traditional project approach, considering the high level of complexity - and uncertainty - regarding the status and vulnerability of species and habitat types, and the potential effects on them from several small-scale or diffuse sources of pollution. It is extremely difficult to assess the potential effects of ammonia emissions from one project, compared to initial load and cumulative effects, as this relies mainly on various types of models and calculations. Moreover, effects from individual projects are often below levels that are detectable or measurable.

An important question is how such certainty is best achieved, bearing in mind the need to ensure a favourable conservation status. In this article, we strongly argue that with regard to ammonia pollution from agricultural activities, it is necessary to combine the Article 6(3) assessment with a programmatic approach, for the following reasons. First, it is hardly feasible to establish a very comprehensive coverage of individual assessment and permit requirements, considering the potentially broad notion of 'projects' as including grazing and fertiliser application under certain circumstances. The poor state of the majority of habitats and species in many Natura 2000 sites, and the quest for certainty as to the absence of adverse effects, required by the CJEU, means that any additional load from a new (or amended) project requires a full assessment, and in most cases would lead to the rejection of such a project (if not justified in accordance with Article 6(4) Habitats Directive). Apart from the substantial administrative burden, this would lead to a deadlock in new development.

Second, using thresholds that allow an additional load from a given project is problematic, unless they comply with the CJEU's strict interpretation, as 
the Dutch thresholds, in our opinion, seem to do. While cut-off or de minimis thresholds that are below detection level are possibly inferior compared to the initial load, and other emissions and activities that may affect the state of a sensitive nature type, the concern for potential cumulative effects remains. Third, considering the scientific uncertainty and cumulative effects of smallscale activities in particular, a higher degree of scientific certainty is probably achievable only at a more aggregate level of assessment. Finally, the actual progress or achievement of a favourable conservation status at either sitelevel or at national level is more dependent on other measures, including general standards applicable to existing installations and active restoration or management measures, than on individual assessment and permit requirements for new or amended livestock installations.

Thus, it appears necessary to consider the linkages between such different measures, and to broaden the scope of ammonia regulation to achieve a favourable conservation status for Natura 2000 habitat types and species. The Dutch programmatic approach attempted to do this, but failed, in view of the rulings of the CJEU and the Dutch Council of State. Nevertheless, a programmatic approach has not been rejected entirely by the CJEU, although the strict criteria may be difficult or almost impossible to fulfil. As long as in many areas the nitrogen deposition far exceeds the critical loads, and habitats and species are often at an unfavourable status, a programmatic approach should not be used in the first instance to (try to) justify further expansion of livestock farming and other projects. Additional loads from expanding livestock farms should be possible only in areas where it is certain that a programmatic approach would lead to an improvement in the conservation status, where this is urgently needed - not only over the long term, but also in the short term. This seems to demand a programmatic approach that, at least in most cases, ensures a constantly declining trend of depositions on Natura 2000 sites. Whether such a trend may be achieved without substantially reducing the number of livestock, or whether significant technological achievements alone may be sufficient, should be clarified in the near future. 